\title{
RUANG INTERPRETATIF: KESADARAN DAN KEPEDULIAN LINGKUNGAN
}

\author{
Yohana $^{1)}$, Franky Liauw ${ }^{2)}$ \\ 1) Program Studi S1 Arsitektur, Fakultas Teknik, Universitas Tarumanagara, yohana.saputraa@gmail.com \\ 2) Program Studi S1 Arsitektur, Fakultas Teknik, Universitas Tarumanagara, frankyl@ft.untar.ac.id
}

\begin{abstract}
Abstrak
Pariwisata telah menjadi salah satu kebutuhan pokok masyarakat era ini. Sebagian besar masyarakat menjadikan pariwisata sebagai kegiatan untuk melepas penat dan beban dari kegiatan dalam kehidupan sehari-harinya. Jakarta sebagai kota metropolis menjadi pusat bagi kota-kota di sekitarnya dalam berbagai kegiatan, sehingga sektor pariwisata dapat memicu perkembangan ekonomi Jakarta dan sekitarnya serta bidang lainnya. Perkembangan sektor pariwisata berjalan sebanding dengan perkembangan teknologi dan jaringan media sosial yang kian meluas. Jaringan yang luas dan teknologi pengambilan gambar yang semakin maju kini menarik masyarakat dalam berwisata dan membagikan cerita perjalanannya dalam jaringan dunia maya. Namun, kemajuan zaman ini pun juga menyebabkan timbulnya masalah di berbagai sektor. Salah satunya yang kerap menjadi perbincagan kota-kota di dunia yaitu masalah lingkungan yang secara umum merupakan akibat dari kegiatan masyarakat itu sendiri. Dalam konteks wisata ekologi, proyek wisata ini menggambarkan akibat dari masalah kerusakan lingkungan tersebut, sehingga wisatawan tidak lagi melihat keindahan alam melainkan suasana yang bertolak belakang yang diakibatkan oleh kegiatan dan kebiasaan hidup mereka, terutama masyarakat perkotaan.
\end{abstract}

Kata Kunci: lingkungan, kerusakan, metropolis, pariwisata.

\begin{abstract}
Tourism has become one of the basic needs of the people of this era. Most people make tourism as an activity to release stress of their routines or daily activities. Jakarta as a metropolis city becomes the center of the surrounding cities in various activities, so that the tourism sector can trigger economic development in Jakarta and its surroundings and other fields. The development of the tourism sector goes hand in hand with the development of technology and social media networks. Extensive network and development in advanced shooting technology, attracts people to travel and share their stories of their journey in social media networks. However, the modernization of this era also caused problems in various sectors. One of them is often becomes a discussion of cities in the world, namely environmental problems, which are generally a result of civilization activities themselves. So, in the context of ecological tourism, this project illustrates the consequences and effects of these environmental damage problems, so that tourists no longer see the beauty of nature but the opposite atmosphere caused by their activities and dailiy habits, especially urban society.
\end{abstract}

Keywords: damage, environmental, metropolis, tourism.

\section{PENDAHULUAN}

Dalam kehidupan metropolis kerap ditemui berbagai masalah. Salah satu tren masalah yang tengah dihadapi seluruh kota metropolis dunia adalah masalah kerusakan lingkungan. Dimulai dari terjadinya efek rumah kaca atau greenhouse effect adalah keadaan di mana panas atau radiasi matahari terperangkap dalam atmosfer bumi, yaitu pada lapisan troposfer. Hal tersebut menyebabkan meningkatnya suhu bumi. Fenomena efek rumah kaca ini disebabkan oleh gas rumah kaca $\left(\mathrm{CO}_{2}, \mathrm{CFC}, \mathrm{CH}_{4}\right)$ yang dihasilkan dari aktivitas manusia. Gas-gas ini menyerap dan memantulkan radiasi matahari, sehingga panas matahari terperangkap dalam lapisan troposfer. Beberapa aktivitas manusia yang menghasilkan gas rumah kaca seperti penggunaan kendaraan bermotor, asap pabrik, penggunaan AC, heater, dan alat listrik lainnya. 
Peningkatan suhu bumi atau pemanasan global yang terjadi ini mengakibatkan kenaikan permukaan air laut. Penelitian Benjamin Strauss pada 2015 melaporkan bahwa setiap 1 derajat Celsius pemanasan iklim akan menyebabkan terjadinya kenaikan permukaan air laut rata-rata global sebesar 2,3 meter.

Jakarta merupakan salah satu kota yang terkena akibat dari kenaikan permukaan air laut ini. Dalam data yang hasil penelitian oleh Climate Central, Jakarta ada pada daftar 10 kota yang terancam akibat kenaikan permuakaan air laut. Pemerintah menyatakan bahwa penurunan permukaan tanah di DKI Jakarta mencapai $7,5 \mathrm{~cm}$ sampai $12 \mathrm{~cm}$ per tahunnya, sehingga diperkirakan seluruh Jakarta Utara akan berada di bawah permukaan air laut pada tahun 2050 (32,5\% dari luas DKI Jakarta).

Salah satu penyumbang pemanasan global terbesar berasal dari karbon dioksida yang dihasilkan oleh kendaraan bermotor. Menurut perhitungan Dewan Transportasi Kota Jakarta, pengguna kendaraan umum pada tahun 2017 baru mencapai 21\%. Sedangkan pada data Badan Pusat Statistik Jakarta ada 18 juta kendaraan bermotor yang beredar di jalanan Jakarta setiap harinya dan rata-rata bertambah $5 \%$ dalam 5 tahun. Menurut badan penelitian INRIX dalam bidang transportasi dan kemacetan, Jakarta merupakan kota peringkat ke 2 di Asia yang paling banyak menghabiskan waktu di jalan. Dari bentuk kemacetan memperlihatkan tingginya polusi udara di Jakarta dan gas emisi karbon yang dihasilkan.

International Institute for Environment and Devlopment Britania juga melakukan penelitian dan memprediksi Jakarta adalah salah satu kawasan yang akan tenggelam dalam abad ini. Kondisi ini juga diperparah dengan keadaan kota Jakarta dengan populasi tertinggi di Indonesia, sehingga dalam perkembangannya lahan terbuka untuk menyerap $\mathrm{CO}_{2}$ makin tidak bersisa karena dibangun gedung-gedung tinggi dan pemukiman penduduk untuk menunjang kehidupan masyarakat. Dnegan meningkatnya pembangunan perkantoran dan perumahan, maka semakin meningkat juga gas emisi $\mathrm{CO}_{2}$ dan $\mathrm{CFC}$ melalui penggunaan listrik dan $\mathrm{AC}$.

Tujuan perencaan proyek adalah menyediakan wisata ekologi sebagai wisata yang menghibur dan mengedukasi untuk masyarakat, sehingga para wisatawan menyalurkan energi dan watunya ke arah yang postif, mendidik dan menghibur. Melalui interaksi antara manusia dan lingkungan alam, wisata ekologi yang dimaksudkan mengarah pada wisata yang memberikan informasi dan meningkatkan kesadaran masyarakat tentang lingkungan hidupnya yang semakin rusak. Sehingga wisatawan ekologi tidak lagi menikmati dan berinteraksi dengan keindahan alam, melainkan melihat realita perubahan yang terjadi pada alam yang telah rusak saat ini. Wisata ekologi ini juga bertujuan untuk memberikan pengertian sehingga meningkatkan kesadaran masayrakat dan merubah perilaku serta pola pikir masyarakat agar lebih ramah lingkungan, terutama mengurangi kegiatan-kegitaan yang merusak lingkungan hidupnya sendiri, dan membekali bahwa perubahan dapat terjadi dimulai dari masing-masing individu.

Untuk mencapai tujuan tersebut, penelitian ini merumuskan pertanyaan penelitian sebagai berikut:

- Bagaimana sistem edukasi yang diterapkan sehingga penyampaiannya efektif dan dapat meningkatkan kesadaran masyarakat?

- $\quad$ Apa saja program yang diterapkan ke dalam ruang interpretasi?

- Bagaimana cara menyusun program dan mendesain fasilitas secara fisik dan non fisik agar ramai dikunjungi oleh wisatawan?

- Bagaimana memadukan ruang interpretasi dengan sarana penghijauan dan ruang terbuka untuk menyumbang area hijau dan area publik dalam lingkungan kota?

\section{KAJIAN LITERATUR}

\section{Architectural Tourism (Architoursim)}

Dengan latar belakang pendidikan di bidang arsitektur, penulis mulai melakukan penelitian dalam bidang arsitektur, rekreasi dan pariwisata karena pengamalannya saat bekerja 
konsultan dan menangani berbagai macam proyek fasilitas pariwisata. Penulis merasa sebagian besar proyek tersebut tidak didasarkan dengan pengetahuan yang cukup atas hubungan keterikatan antara arsitektur dan pariwisata, dan pihak-pihak yang terkait juga tidak memahami apa yang menjadi ketertarikan dan harapan turis dari berbagai macam program arsitektur.

Teori mengenai hubungan saling keterikatan yang terjadi antara arsitektur (architecture) dan pariwisata (tourism) dan kemunculan istilah "architourism" bermula dari konferensi yang diselenggarakan oleh Frausto dan Ockman tentang "Interdependencies of Tourism and Architecture" pada tahun 2002. Konferensi ini diadakan berdasarkan atas kontroversi tentang kesuksesan Guggenheim Museum oleh Frank Gehry, yang mengangkat ekonomi Bilbao atau yang dikenal dengan Bilbao Effect, sehingga arsitektur dinilai penting terhadap ekonomi lokal dan nasional.

Arsitektur dapat menjadi daya tarik dan tujuan parwisata para turis datang ke sebuah kota. Arsitektur dapat merubah image sebuah kota sebagai tujuan wisata, baik dari keindahan alam dan monumen sejarah yang dimiliki, atau dari lingkungan buatan yang menjadi landmark dengan wujud visual yang dapat menarik perhatian dan minat para turis. Nilai pengakuan dapat menjadi alasan yang dominan mengapa arsitektur dapat menjadi simbol pariwisata sebuah kota, karena turis mencari tujuan wisata yang photogenic dan mencari pengakuan atas kunjungannya melalui fotonya pada objek wisata yang menjadi icon sebuah kota, dan membagikannya kepada keluarga, teman, kerabat melalui media massa yang sedang berkembang. Maka terdapat hubungan yang erat antara pariwisata, arsitektur dan fotografi.

Untuk menjadikan arsitektur sebagai simbol tujuan pariwisata, maka diperlukan sebuah arsitektur yang spektakular dan dapat menjadi tontonan yang memukau para turis. Maka itu dalam perancangan, sering kali konsep form follows function digantikan dengan function follows form, seperti halnya pada Guggenheim Museum yang menarik mayarakat kota Bilbao karena bentuk bangunannya yang tak pernah mereka temui.

Museum of Islamic Art di Doha. Arsitektur yang spektakuler memberikan kontribusi untuk menciptakan brand destinasi wisata yang kuat, dan membentuk image destinasi yang berciri khas. Skyline Doha dilihat dari Museum of Islamic Art menjadi sebuah objek fotografi yang dicari para wisatawan.

Dari masa ke masa, para turis mencari tujuan wisata yang spektakuler dan memukau. Awal mula pariwisata dimulai dari perjalanan para peziarah untuk menyaksikan keindahan situs religi. Berlanjut sampai abad ke 17 tujuan melakukan perjalanan pariwisata untuk menyaksikan keindahan keindahan peninggalan klasik antik jaman Reinassance. Hingga sekarang sudah menjadi mindset para turis untuk mencari tempat wisata yang indah dan mencari tontonan yang spektakuler.

\section{Wisata Ekologi}

Beberapa prinsip dan/atau konsep dasar dalam wisata ekologi pada umumnya terkait dengan srtuktur dan fungsi organisma; metabolisme; hukum kekekalan energi; konservasi materi dan faktor pembatas.

Dari pengertian diatas maka Ekologi adalah ilmu mengenai hubungan timbal-balik antar unsur hayati dengan tata alam disekitarnya (Erast Haeckal, 1865). Hubungan timbal balik ini merupakan irama kehidupan alami, yang disebut ekosistem.

Ekosistem ini juga terdapat di dalam tubuh manusia, baik rohani maupun jasmani. Juga terdapat di angkasa luar. Seandainya ekosistem dalan tubuh manusia terganggu, terganggu pula kesehatan manusia. Demikian pula dengan alam, jika ekosistem alam terganggu, terganggu pula tata alaminya. Hal iniakan meluas sehingga mengganggu kehidupan manusia, termasuk unsur hayati lain.

Menurut Kementrian Pariwisata dan Ekonomi Kreatif RI, dengan melihat potensi yang dimiliki Indonesia, maka disusun Visi Ekowisata Indonesia yaitu untuk menciptakan 
pengembangan pariwisata melalui penyelenggaraan yang mendukung upaya pelestarian lingkungan (alam dan budaya), melibatkan dan menguntungkan masyarakat setempat serta menguntungkan secara komersial. Visi Ekowisata tersebut di dasarkan pada beberapa unsur utama, karena:

- Ekowisata sangat tergantung pada mutu sumber daya alam, peninggalan sejarah dan budaya.

- Melibatkan masyarakat, masyarakat yang menetap disuatu tempat (tujuan wisata)

- Ekowisata meningkatkan kesadaran dan apresiasi terhadap alam, nilai-nilai peninggalan sejarah dan budaya.

- Pertumbuhan pasar ekowisata di tingkat internasional, regional dan nasional.

- Ekowisata sebagai sarana mewujudkan ekonomi berkelanjutan. Beberapa Profil Wisata Ekologi menurut Kementrian Pariwisata dan Ekonomi Kreatif RI antara lain:

- Meningkatkan pengalaman yang asli dan mendalam

- Mencari tantangan fisik dan mental

- Mengharapkan pengalaman berintegrasi social dengan masyarakat setempat

- Mau mempelajari kebudayaan masyarakat setempat

- Mudah menyesuaikan diri

- Toleransi terhadap ketidaknyamanan

- Ingin ikut terlibat, tidak bersifat pasif

- Lebih suka membayar untuk petualangan daripada untuk kenyamanan.

\section{Tinjauan Umum Ruang Interpretatif}

Ruang Interpretatif atau Interpretive space adalah wadah dan lembaga untuk penyebaran pengetahuan tentang warisan alam atau budaya, museum gaya baru yang sering dikaitkan dengan visitor center yang berlokasi di situs yang berhubungan dengan aspek yang ingin disampaikan. Menggunakan sarana komunikasi yang berbeda untuk memerikan pemaahaman, proses pemahamannya melalui hubungan intelektual dan emosional pengunjung dengan strategi presentasi yang interaktif dan user-friendly. Tidak seperti museum tradisional, pusatpusat interpretasi tidak bertujuan untuk mengumpukan, melestarikan dan mempelajari objek, mereka mengkomunikasikan signifikansi dan arti dari sebuah warisan alam atau budaya, mereka mendidik dan meningkatkan kesadaran.

\section{Ruang}

Ruang merupakan elemen yang sangat penting dalam arsitektur. Secara harfiah, ruang (space) berasal dari bahasa Latin, yaitu spatium yang berarti ruangan atau luas (extent). Jika dilihat dalam bahasa Yunani dapat diartikan sebagai tempat (topos) atau lokasi (choros) yaitu ruang yang memiliki ekspresi kualitas tiga dimensi. Menurut Aristoteles, ruang adalah suatu yang terukur dan terlihat, dibatasi oleh kejelasan fisik, enclosure yang terlihat sehingga dapat dipahami keberadaanya dengan jelas dan mudah. Sedangkan dalam pemikiran timur, menurut Lao Tzu, Sebuah ruang tidak memerlukan pembatas yang jelas atau tegas, tetapi lebih mengandalkan perasaan. Ruang bisa terbentuk lewat berbagai macam cara seperti perbedaan ketinggian, perbedaan warna dan bahan, tata pencahayaan, dll.

Ruang tidak dapat di pisahkan dari kehidupan manusia, baik secara psikologi, emosional, dan dimensional. Manusia berada dalam ruang, bergerak, menghayati, berfikir dan juga menciptakan dan menyatakan bentuk dirinya.

Salah satu jenis ruang kehidupan manusia adalah ruang bawah tanah. Ruang bawah tanah biasanya dikenal sebagai lingkungan tertutup di bawah permukaan bumi. Ini berarti bahwa tidak seperti lingkungan yang dibangun di atas tanah, tidak ada akses langsung ke ruang terbuka terbuka (Ringstad, 1994). Dengan demikian, pengguna ruang bawah tanah tidak mendapatkan pandangan lurus dari keadaan/kejadian yang sedang berlangsung di luar 
ruangan. Dalam ruang bawah tanah seringkali terjadi perasaan terjebak karena hilangnya kontrol atas lingkungan yang dapat menyebabkan ketidaknyamanan dan reaksi klaustrofobia (Hane et al., 1991; Ringstad, 1994). Selain itu, karena tidak adanya sinar matahari dan pemandangan alam, ruang cenderung lebih gelap tanpa banyak variasi sepanjang hari. Kurangnya rangsangan ini tampaknya mengakibatkan ketidaksenangan dan disorientasi saat berada di ruang bawah tanah (Hane et al., 1991).

Ada berbagai kepercayaan masyarakat tentang ruang bawah tanah, yang berasal dari zaman kuno. Misalnya, Kekristenan menggambarkan dunia bawah tana sebagai neraka (Lesser, 1987). Demikian juga, Taoisme dan Buddhisme berhubungan di bawah tanah dengan konsep "diyu", ranah orang mati dalam kepercayaan budaya Cina. Selain keyakinan agama ini, praktik pemakaman manusia adalah hal yang umum di masyarakat Timur dan Barat. Hal ini menghasilkan kesan bahwa tinggal di bawah tanah seperti dikubur, yang menambah asosiasi bahwa dunia bawah tanah merupakan kematian (Sommer, 1974; Hane et al., 1991). Secara keseluruhan, tampaknya ada banyak konotasi negatif ruang bawah tanah dalam lintas budaya.

\section{Interpretasi}

Interpretasi menurut KBBI adalah pemberian kesan, pendapat, atau pandangan teoretis terhadap sesuatu / tafsiran. Interpretasi adalah seni yang menggambarkan komunikasi secara tidak langsung, namun komunikasi tersebut dapat dengan mudah untuk dipahami. Interpretasi erat kaitannya dengan jangkauan yang harus dicapai oleh subjek dan sekaligus pada saat yang bersamaan diungkapkan kembali sebagai suatu struktur identitas yang terdapat di dalam kehidupan, sejarah dan objektivitas. (Kaelan : 1998). Jadi secara umum, interpretasi dapat diartikan sebagai tafsiran, penjelasan, makna, arti, kesan, pendapat, atau pandangan teoritis terhadap suatu objek yang dihasilkan dari pemikiran yang mendalam dan sangat dipengaruhi oleh latar belakang orang yang melakukan interpretasi.

Setiap objek dapat seperti buku, puisi, patumg, lukisan, data dan lainnya dapat menjadi objek interpretasi. Interpretasi biasanya dilakukan untuk mendapatkan pengertian atau pengetahuan yang lebih jelas dan mendalam tentang sesuatu. Misalnya sebuah lukisan abstrak yang kurang bisa dipahami maksudnya bagi sebagian besar orang. Lukisan ini dapat menjadi objek interpretasi sehingga orang awam dapat mengetahui makna yang terkanduung pada lukisan tersebut.

Interpretasi sangat bergantung dari sudut pandang dan latar belakang orang yang menginterpretasikan. Sehingga interpretasi terhadap objek yang sama bisa berbeda hasilnya jika dilakukan oleh orang yang berbeda.

\section{METODE}

Dalam proses penulisan Tugas Akhir ini, menggunakan metode pembahasan dengan 3 tahap :

- Tahap pengumpulan data. Pengumpulan data ini dilakukan dengan cara:

- Melakukan survey ke lapangan, wawancara, dan observasi.

- Melakukan studi literatur.

- Tahap analisa. Metode yang digunakan dalam melakukan analisa adalah :

- Induksi, yaitu menarik kesimpulan dari fakta-fakta yang ada.

- Komparasi, yaitu nilai, melakukan penganalisaan dengan bahan-bahan yang didapat dari observasi, pengumpulan data dan studi literatur.

- Tahap Sintesa. Tahap ini merupakan tahap perumusan konsep dengan menggunakan metode deduksi, yaitu membuat perumusan dari hasil induksi. 


\section{DISKUSI DAN HASIL}

\section{Analisis Kawasan}

Data BPS menegenai objek wisata unggulan menurut lokasi pariwisata di DKI Jakarta meneyebutkan 8 objek wisata yang diantaranya berlokasi di Jakarta Utara yaitu Taman Impian Jaya Ancol, Pelabuhan Sunda Kelapa dan Museum Sejarah Jakarta yang berada dalam kawasan wisata Kota Tua. Maka dari itu dapat dikatakan bahwa wisata di Kota Administratif Jakarta Utara identik dengan wisata bahari atau kelautan dan wisata edukasi di kota tua yang sebagian berada di Jakarta Utara.

Image kota administratif Jakarta Utara ini berkaitan dengan tema proyek yang diangkat yaitu mengenai kelautan dalam bentuk sarana edukasi dan informasi. Di mana dari data BPS yang disebutkan di atas dapat diketahui tujuan wisatawan di kawasan ini mengarah pada wisata bahari dan wisata edukasi.

\section{Kecamatan Penjaringan dan Pademangan}

Untuk membuat objek wisata maka kawasan terpilih berada dalam jalur wisatawan. Kawasan wisata di Jakarta Utara yang termasuk di dalam wisata unggulan dari data BPS berada pada kawasan kecamatan Penjaringan dan Pademangan. Di mana yang dimaksudkan berlokasi pada kecamatan Pademangan adalah area wisata Taman Impian Jaya Ancol, yaitu wisata di Jakarta yang paling banyak dikunjungi wisatawan sampai saat ini. Pada Kecamatan Penjaringan; adalah area pelabuhan Sunda Kelapa, yaitu lokasinya bersebelahan dengan Museum Bahari yang masih berada dalam Kawasan Wisata Kota Tua.

\section{Kawasan Museum Bahari}

Setelah melakukan perbandingan tapak, maka tapak yang terpilih berada di Jalan Pakin Museum Bahari, Penjaringan. Alasan-alasan yang mendasari pemilihan tapak adalah:

- Kawasan Pelabuhan Sunda Kelapa dan Museum Bahari besinggungan langsung dengan tema yang diangkat yaitu kelautan dalam bentuk edukasi dan informasi, sehingga kawasan ini dapat menjadi simpul keduanya yaitu wisata bahari dan wisata edukasi menurut lokasi dan programnya.

- Melihat potensi kawasan ini di mana Museum Bahari masih termasuk kawasan wisata Kota Tua, yaitu salah satu kawasan besar yang dikonservasi di Jakarta yang ramai didatangi wisatawan lokal dan mancanegara.

- Berada tepat pada jalur pengembangan koridor LRT, yaitu koridor Museum Bahari.

Tapak terpilih berada di Jalan Pakin sebelah Museum Bahari, dengan lebar jalan akses masuk 6 meter untuk kendaraan dari 2 arah. Memiliki profil berupa:

- Luas Tapak: $15.596 \mathrm{~m}^{2}$

- KDB: 60\% / KLB: 2.0 / KTB: 55\% / KB: 4 / KDH: 30\%
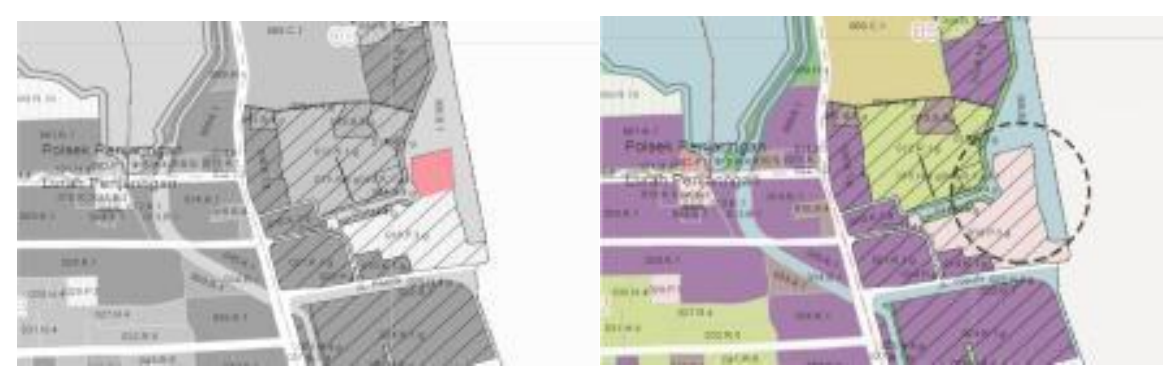


\section{pemerintahan daerah}

parkir, puskesmas, klinik hewan, pusat informasi lingkungan, kolam retensi, taman kota, hutan kota, kepentingan pertah. anan $\mathbf{B}$

merupakan kegiatan yang masuk dalam kategori diizinkan.

\section{Gambar 1. Tata Guna Lahan Kecamatan Penjaringan} Sumber: RDTR Jakarta

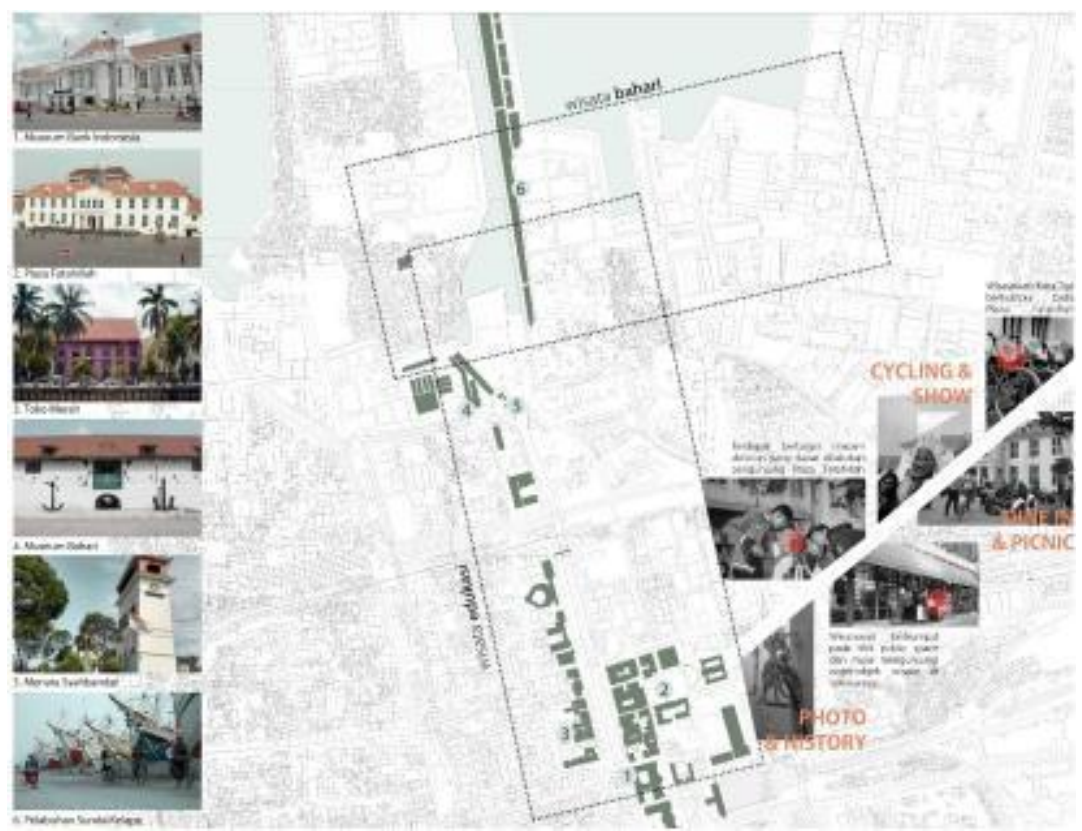

Gambar 2. Analisa Tapak terhadap Kawasan Kota Tua Sumber: Olahan penulis, 2018

Kawasan Pelabuhan Sunda Kelapa dan Museum Bahari besinggungan langsung dengan tema yang diangkat yaitu kelautan dalam bentuk edukasi dan informasi, sehingga kawasan ini dapat menjadi simpul keduanya yaitu wisata bahari dan wisata edukasi menurut lokasi dan programnya. Selain melihat potensi kawasan ini di mana Museum Bahari masih termasuk kawasan wisata Kota Tua, yaitu salah satu kawasan besar yang dikonservasi di Jakarta dan banyak dikunjungi wisatawan baik lokal dan mancanegara (terutama pada akhir pekan dan hari besar) karena beragam aktivitas maupun sejarah yang disuguhkan.

Namun kawasan ini nampak sebagai kawasan yang kurang dijangkau oleh wisatawan Kota Tua karena kendala dalam segi transportasi dan segi aktivitas. Dari pengamatan yang dilakukan karena kurangnya public space dan aktivitas pendukung, seperti halnya pada public space di Kota Tua yang mengundang banyak wisatawan untuk berkumpul pada Plaza Fatahillah dengan beragam aktivitas. Tidak sedikit wisatawan yang awalnya datang hanya untuk bersantai dan berkumpul di Fatahillah Square memutuskan untuk bersinggah pada museum, café dan menghabiskan setengah sampai dengan satu hari di area Kota Tua. 


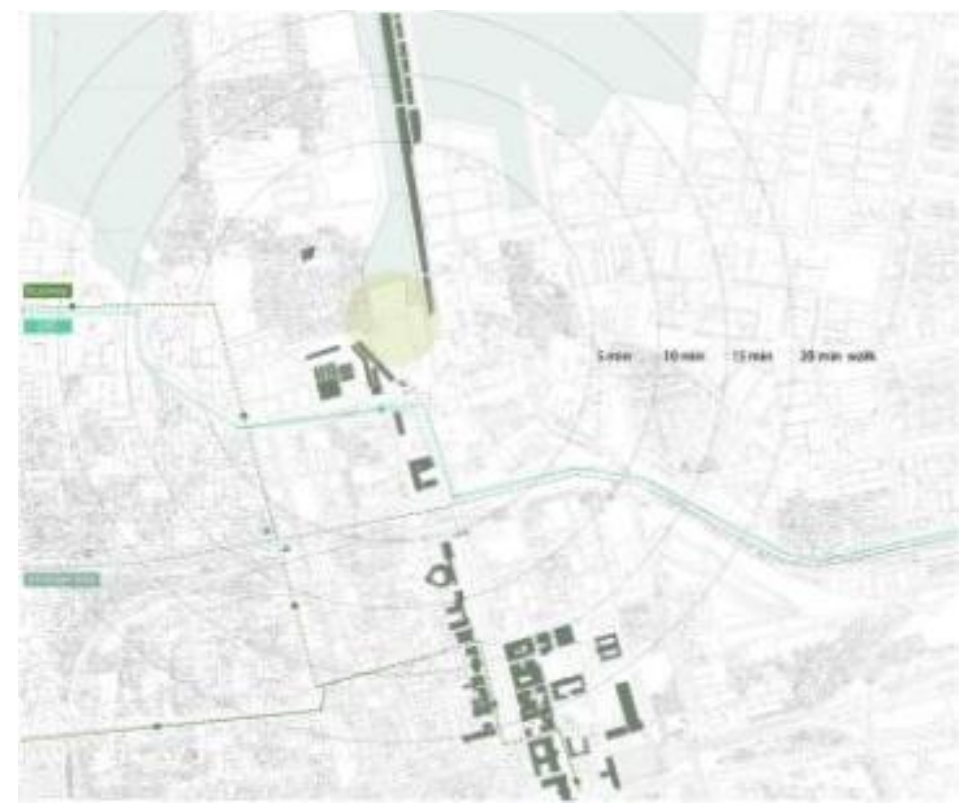

Gambar 3. Analisa Tapak terhadap Kawasan Kota Tua Sumber: Olahan penulis, 2018

Dari segi transportasi, transportasi umum di Jakarta terus berkembang dengan penambahan koridor Transjakarta, LRT dan MRT, yang beberapa diantaranya melewati kawasan Museum Bahari, sehingga tapak ini memliki potensi untuk pengembangan ke depannya.

Tapak berada langsung pada rencana koridor LRT yaitu koridor Museum Bahari dan berjarak 450 meter dari Halte Transjakarta Pakin. Letak tapak juga dipinggir jalur tol dalam kota, yaitu 800 meter dari pintu keluar tol Sunda Kelapa, sehingga memudahkan mobilitas ke berbagai bagian kota di Jakarta.

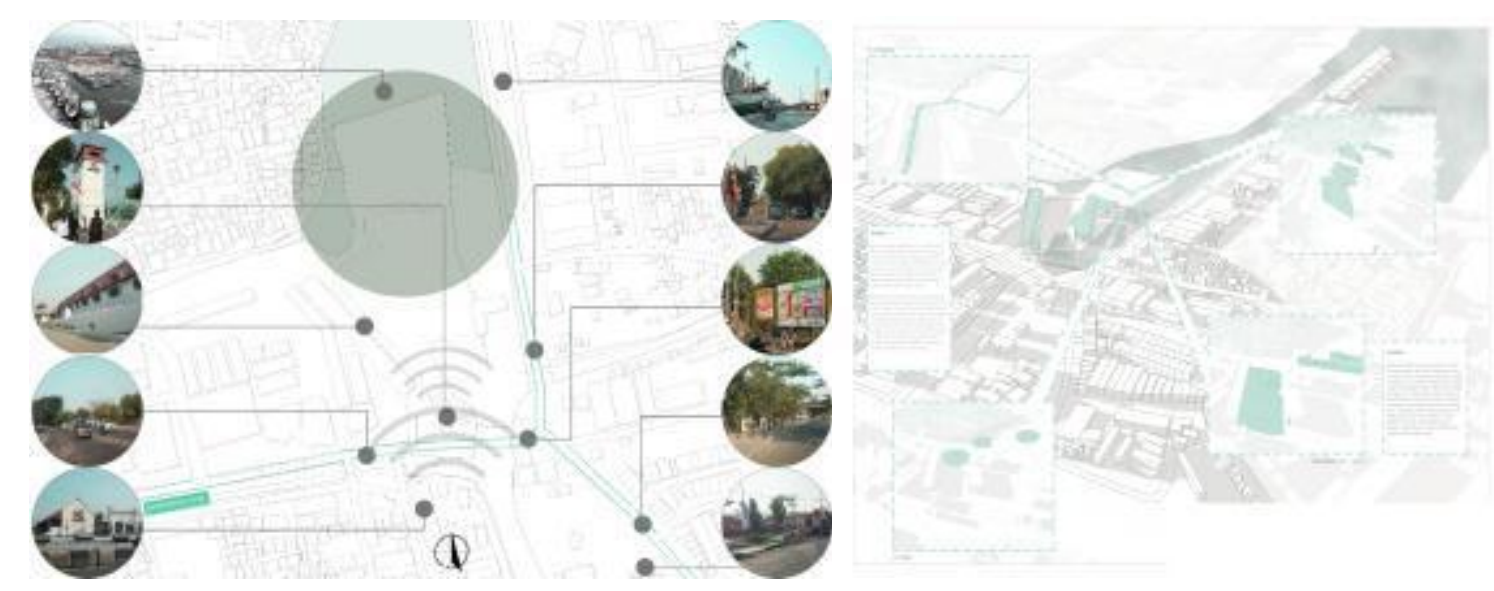

Gambar 4. Analisa Tapak

Sumber: Olahan penulis, 2018

Jalan masuk ke dalam tapak digerbangi oleh 2 objek wisata konservasi yaitu Menara Syahbandar dan Museum Bahari. Dari segi orientasi, view menghadap utara dapat dimanfaatkan karena langsung berhadapan dengan laut dan Pelabuhan Sunda Kelapa, dapat dijadikan potensi area promenade yang jarang ditemui di Jakarta. Dari segi jalur pedestrian, terlihat beberapa wisatawan lokal dan asing berjalan dari arah Kota Tua meunju Kawasan Bahari. Jika dilihat dari lalu lintas di jalan depan tapak yang cukup padat pada hari kerja, polusi 
dan kebisingan dari kendaraan tidak terlalu mengganggu karena posisi tapak yang tidak dipinggir jalan.

Akses menuju tapak hanya 1 yaitu melalui Museum Bahari dari Jalan Pakin. Sehingga jalan itu menjadi jalur kendaraan pengunjung dan servis, dengan pemisahan jalur pejalan kaki. Jalur kendaraan hanya mencapai Pasar Hexagon, sehingga area tapak ke dalam bebas kendaraan dan dapat digunakan untuk open public space.

Terdapat 3 titik view di dalam tapak. Ketiga titik ini dijadikan sebagai nodes yang berupa public space. Yang pertama berada pada entrance tapak di antara dua bangunan sejarah. Yang kedua berada pada tengah tapak, di mana pada titik ini jika dielevasi dapat menjangkau semua objek wisata di sekitar tapak. Yang ketiga berada di ujung tapak pada pinggir laut yang bersebelahan langsung dengan Pelabuhan Sunda Kelapa.

Aktivitas terjadi mayoritas pada sore hari. Pembayangan dari massa bangunan dan bangunan lain di sekitarnya dapat menjadi naungan untuk aktivitas pada open public space di sebagian besar waktu antara pagi hingga sore. Public Space pada entrance diposisikan di antara area yang mendapat naungan dari pagi hingga sore (terutama sore). Terdapat 2 titik massa bangunan di area tapak yang harus dielevasi untuk dapat menaungi 2 titik public space lainnya (berdasarkan nodes tadi), baik di waktu pagi maupun sore.

\section{Program dan Kegiatan}

Area Informasi

- Ruang Kontemplasi Drowning City, area penyampaian informasi melalui pendekatan emosi pengunjung dengan pengalaman ruang dan pameran interaktif. Menceritakan tentang kerusakan alam dan aktivitas manusia yang menjadi akar penyebabnya.

- Ruang Simulasi Drowning City, area penyampaian informasi melalui pengalaman ruang yang dapat dirasakan langsung secara fisik. Menceritakan akibat yang terjadi akibat kerusakan yang digambarkan pada area kontemplasi.

- Ruang Kontemplasi Sustainable City, area penyampaian informasi melalui penggambaran suasana kota yang kontras dengan Drowning City, memberikan gambaran lingkugan bebas yang tetap ada bila masyarakat telah memulai perubahan dengan kesadaran akan kerusakan lingkungan.

Area Edukasi

- Ruang Edukasi Sustainable City, area penyampaian edukasi tentang perubahan yag dapat dilakukan setiap individu untuk menjaga lingkungan hidupnya, dengan pameran bersifat aktif-pasif dan pasif-pasif.

- Ruang Studio, untuk presentasi dan event temporer.

Area Publik Penunjang

- Public Plaza, menyumbang dalam area ruang terbuka dan aktivitas kota yang dapat dipakai untuk pertunjukan dan event temporer.

- Restoran Vegetarian, mengganti menu dengan menu vegetarian karena menurut data PBB $18 \%$ dari pemanasan global disumbangkan oleh industri perternakan, selain menjadi penghasil $\mathrm{CO}_{2}$ yang besar, insutri peternakan juga merupakan penyebab terjadinya pencemaran tanah dan pencemaran air pada lingkungan.

- Market, untuk menunjang perubahan dengan menjual alat-alat kebutuhan rumah tangga hemat listrik.

\section{Proses Pembentukan Gubahan Massa}

Secara keseluruhan tapak dibagi menjadi 3 fase yang menggambarkan suasana berbeda. Pada alur pertama di entrance suasana hijau yang didominasi pepohonan. Lalu berjalan ke dalam suasana hijau mulai berkurang dan lingkungan mulai didominasi oleh air. Pada akhirnya berhenti di pinggir laut di mana daratan dikelilingi dan didominasi oleh air lautan. 
Massa bangunan dibentuk berdasarkan titik view yang menjadi penting karena site dikelilingi oleh bangunan2 wisata. Terdapat 3 titik view yang dijadikan nodes sebagi public space. Titik pertama berada pada entrance yang berada diantara 2 bangunan bersejarah. Titik kedua berada pada tengah site dimana jika dielevasi titik ini dapat menjangkau semua objek di sekitarnya. Dan titik ketiga berada dipinggir laut yang berbatasan langsung dengan pelabuhan sunda kelapa. 3 titik ini dihubungakan lalu menjadi alur utama sirkulasi pengunjung. Massa bangunan dibuat menyatu dengan alur sirkulasi pengunjung ini.

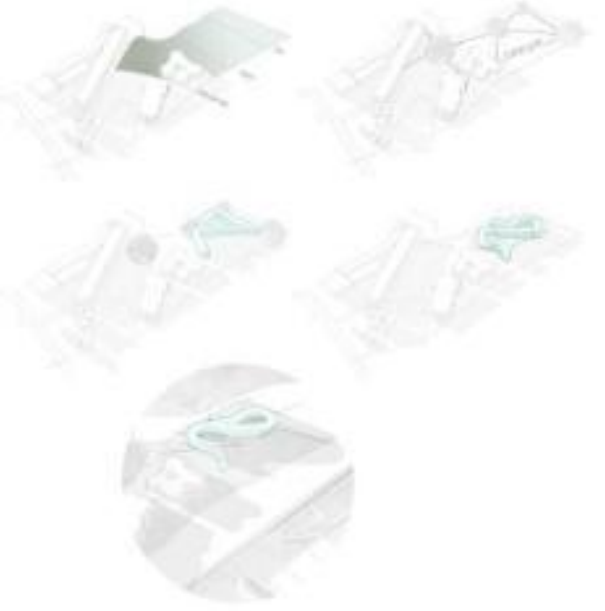

Gambar 5. Proses Pembentukan Gubahan Massa

Sumber: Olahan penulis, 2018

\section{Konsep Perancangan}

Di dalam proyek ini berisi rangkaian alur cerita yang digambarkan dan disampaikan kepada pengunjung melalui pengalaman ruang. Mulai dari ruang kontemplasi, ruang simulasi dan ruang edukasi yang bertujuan untuk menyadarkan masyarakat tentang masalah lingkungan yang sedang terjadi terhadap lingkungan hidupnya dan mengubah perilaku masyarakat agar lebih ramah lingkungan.

Rangkaian alur ini dilalui pengunjung melalui sirkulasi dengan konsep escaping hill. Di mana alur dimulai dari titik terendah di bawah muka tanah kemudian semakin naik menuju ke titik tertinggi di atas muka laut, menggambarkan masalah penurunan permukaan tanah dan kenaikan permukaan air laut serta dampaknya terhadap aktivitas manusia, sehingga membutuhkan dataran atau pijakan yang lebih tinggi.

Alur dimulai dari plaza pada entrance lalu mulai turun ke bawah dengan ramp yang dibatasi oleh kaca air dan berhenti pada underground plaza yang menggambarkan perpindahan aktivitas publik karena terjadinya penurunan permukaan tanah. Lalu ruang lobby merupakan ruang kaca yang dikelilingi air yang langsung bersebelahan langsung dengan ruang kontemplasi sehingga aktivitas di lobby dapat dilihat dari dalam.

Selanjutnya masuk ke ruang kontemplasi drowning city, ruang yang dikelilingi air menggambarkan suasana kota akibat kerusakan lingkungan dengan ruang bawah tanah yang gelap dan minim cahaya dengan reruntuhan bangunan dan perabotan yang tenggelam. Membuat pengunjung merasakan rasa takut. Berlanjut ke ruang simulasi drowning city menceritakan efek dari kerusakan lingkungan dengan interaksi langsung dengan pengunjung, berupa ruangan hampa dengan permukaan air yang tidak tetap dalam bentuk labirin dan jalan buntu dan sedikit lubang cahaya di atasnya, membuat pengunjung merasakan bahwa mereka sudah jauh di bawah, menciptakan rasa panik dan ketidakleluasaan berada di bawah air. Setelah berlanjut, fase ruang berikutnya adalah menuju ruang edukasi sustainable city berisi informasi tentang perubahan apa saja yang setiap individu dapat lakukan untuk mengurangi kerusakan lingkungan. Mulai dari ruang gelap bawah tanah yang semakkin lama mengarah ke ruang yang terang dan terbuka; membuat pengunjung merasakan harapan untuk keluar. Lalu 
terhubung ke ruang kontemplasi sustainable city, dimulai dari jembatan yang berada di atas tanah yang dikelilingi pepohanan sepanjang jalurnya, menciptakan suasana yang kontras dari alur-alur sebelumnya. Alur ini berlanjut semakin lama semakin naik hingga berujung pada titik tertinggi bangunan dimana pengunjung dapat merasakan suasana alam lepas ke arah laut.

Kemudian saat berjalan turun bertemu dengan cafe. Suasana ruang pada Cafe ini memanfaatkan pasang surut air laut. Didepan cafe terdapat selasar dan jembatan apung untuk mendapatkan view dan suasana laut.

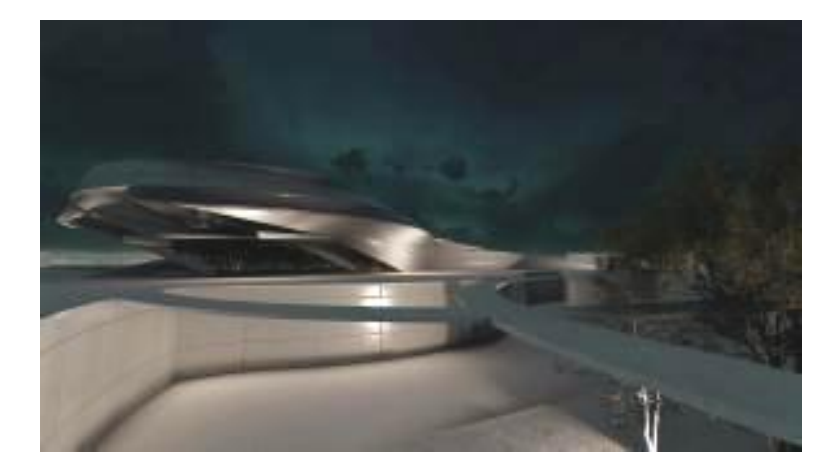

Gambar 6. Perspektif Eksterior - Underground Plaza Sumber: Olahan penulis, 2018

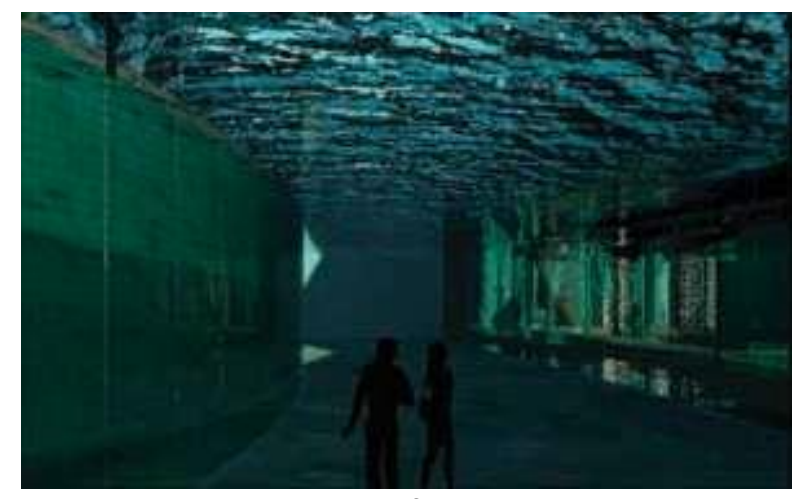

Gambar 7. Perspektif Interior - Lobby

Sumber: Olahan penulis, 2018

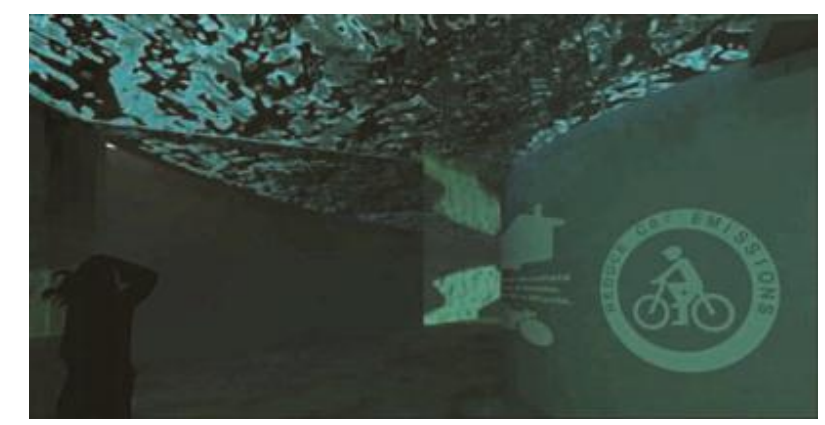

Gambar 8. Perspektif Interior - Ruang Edukasi Sustainable City Sumber: Olahan penulis, 2018

Gambar 9. Perspektif Interior - Ruang Simulasi Drowning City

Sumber: Olahan penulis, 2018

\section{KESIMPULAN DAN SARAN}


Dari data-data hasil berbagai badan penelitian, tampak kesadaran masyarakat kota Jakarta akan masalah lingkungan yang dihadapi saat ini masih minim. Untuk itu dibutuhkan sarana yang dapat menyadarkan kembali setiap individu dalam masyarakat akan pentingnya mengambil peran dan partisipasi dalam menangani berbagai macam masalah yang terjadi pada lingkungan hidupnya.

Ruang interpretatif atau interpretive space sebagai wisata ekologi yang menghibur dan mengedukasi untuk masyarakat, sehingga para wisatawan menyalurkan energi dan watunya ke arah yang positif, mendidik dan menghibur. Melalui interaksi antara manusia dan lingkungan alam, wisata ekologi yang dimaksudkan mengarah pada wisata yang memberikan informasi dan meningkatkan kesadaran masyarakat tentang lingkungan hidupnya yang semakin rusak. Sehingga wisatawan ekologi tidak lagi menikmati dan berinteraksi dengan keindahan alam, melainkan melihat realita perubahan yang terjadi pada alam yang telah rusak saat ini. Wisata ekologi ini juga bertujuan untuk memberikan pengertian sehingga meningkatkan kesadaran masyarakat dan merubah perilaku serta pola pikir masyarakat agar lebih ramah lingkungan, terutama mengurangi kegiatan-kegiatan yang merusak lingkungan hidupnya sendiri, dan membekali bahwa perubahan dapat terjadi dimulai dari masing-masing individu.

\section{UCAPAN TERIMA KASIH}

Penulis mengucapkan terima kasih kepada Tuhan Yang Maha Esa karena atas berkatNya artikel Jurnal Stupa ini dapat terselesaikan dengan baik. Penulis juga mengucapkan terima kasih kepada dosen fasilitator utama dan dosen fasilitator pendamping yang telah meluangkan waktu, tenaga, dan pikiran dan telah banyak membantu dalam proses pengerjaan artikel Jurnas Stupa ini.

\section{REFERENSI}

Abrecombie. (1984). Fungsi, Ruang, Bentuk dan Ekspresi dalam Arsitektur. http://www.academia.edu/15341427/FUNGSI RUANG BENTUK DAN EKSPRESI DALAM A RSITEKTUR (diakses tanggal 5 Agustus pukul 19.10)

Alicia, Nesa. (2018). Penurunan Permukaan Tanah, Jakarta Utara Tenggelam 32 Tahun Lagi? http://nationalgeographic.grid.id/read/13931978/penurunan-permukaan-tanah-jakartautara-tenggelam-32-tahun-lagi?page=all (diakses tanggal 5 September 2018 pukul 18.20)

Ching, Francis D. K. (2000). Arsitektur: Bentuk, Ruang dan Tatanan. Jakarta: Erlangga

Divine, David. (2013). Interpretive Spaces: Narratives of Places and Spaces http://ewds.strath.ac.uk/Portals/50/ias\%20documents/Reclaiming\%20Lost\%20Childhoods/ David\%20Divine-Interpretive\%20Spaces.pptx (diakses tanggal 12 September 2018 oukul 10.15)

Haeckal, Erast. (1865). Hubungan Ekologi Ilmu Lingkungan dan Lingkungan. http://www.academia.edu/6736284/HUBUNGAN EKOLOGI ILMU LINGKUNGAN DAN LIN GKUNGAN HIDUP Ekologi -Catatan2 Hipocartus (diakses tanggal 12 Juli pukul 21.10)

Hane dkk. (1991). Psychological Effects of Working Underground. https://www.researchgate.net/publication/223675359 Psychological effects of working underground (diakses tanggal 12 Juli pukul 23.15)

Kaelan. 1998. Pengertian Interpretasi Menurut Para Ahli. http://www.pengertianmenurutparaahli.net/pengertian-interpretasi/ (diakses tanggal 12 Agustus pukul 10.20)

Lang. (1987). Fungsi, Ruang, Bentuk dan Ekspresi dalam Arsitektur. http://www.academia.edu/15341427/FUNGSI RUANG BENTUK DAN EKSPRESI DALAM A RSITEKTUR (diakses tanggal 5 Agustus pukul 19.10)

Lesser. 1987. A Psychological Approach to Understand Underground Spaces. https://www.ncbi.nlm.nih.gov/pmc/articles/PMC5368185/ (diakses tanggal 13 Juli pukul 00.05) 
Maciocco, Giovanni dan Silvia Serreli. 2009. Enhancing the City: New Perspectives for Tourism and Leisure. New York: Spinger

Muggah, Por Robert. 2017. Cities Are On the Front-Line of Climate Change, They must Adapt or Die. https://igarape.org.br/cities-are-on-the-front-line-of-climate-change-they-must-adaptor-die/ (diakses tanggal 15 Juli pukul 14.15)

Ringstad. 1994. The Design of Underground Faciilities for Public Use. https://www.researchgate.net/publication/223405268 Perceived danger and the design of underground facilities for public use (diakses tanggal 12 Juli pukul 23.30)

Smithies. 1984. Fungsi, Ruang, Bentuk dan Ekspresi dalam Arsitektur. http://www.academia.edu/15341427/FUNGSI RUANG BENTUK DAN EKSPRESI DALAM A RSITEKTUR (diakses tanggal 5 Agustus pukul 19.10)

Specht, Jan. 2014. Architectural Tourism: Building for Urban Travel Destinations. New York: Spinger

Susandi. 2007. Measurement in Climate Change in Jakarta. https://citynet-ap.org/wpcontent/uploads/2011/12/CLIMATE CHANGE MEASURES-Dhaka 27 November 2011.pdf (diakses tanggal 15 Juli pukul 14.40)

Veverka, John. 2011. Planning Truly Interpretive Exhibits. https://portal.unifreiburg.de/interpreteurope/service/publications/recommendedpublications/veverka truly interpretive exhibits.pdf (diakses tanggal 11 September 2018 pukul 20.10)

https://iakarta.bps.go.id/backend/pdf publikasi/Statistik-Transportasi-DKI-Jakarta-2015.pdf (diakses tanggal 15 Juli 2018 pukul 18.20)

http://www.kemenpar.go.id/userfiles/LAKIP\%20DEPUTI\%20BPDIP\%202015.pdf (diakses tanggal 11 September 2018 pukul 18.30) 